DOI: 10.5613/rzs.44.2.4 »Reproduciranje zajedničkoga«, ali se

\section{Silvia Federici}

\section{Revolution at Point Zero: Housework, Reproduction, and Feminist Struggle}

Oakland, CA: PM Press; Brooklyn, NY: Common Notions, Autonomedia, 2012, 188 str.

Knjigu Silvije Federici, povjesničarke i dugogodišnje aktivistice s prebivalištem u SAD-u, Revolution at Point Zero: Housework, Reproduction, and Feminist Struggle, čini zbirka eseja koje je autorica napisala između 1975. i 2010. godine. Iako sadržajno drukčiji, njezini su eseji ipak povezani s centralnom temom koja se kroz njih provlači - problematiziranjem pitanja »društvene reprodukcije« shvaćene kao skup praksi i odnosa kroz koje pojedinci na svakidašnjoj osnovi rekonstituiraju svoje živote i svoju radnu snagu (str. 1). U esejima autorica posebno raspravlja društvenu reprodukciju kroz njezin odnos spram kapitalističkog načina proizvodnje (kapitalizma), kroz ulogu koju društvena reprodukcija ima $u$ takvom sustavu te kroz posljedice koje takva organizacija ekonomije ima po nejednak položaj žena u društvu, ali i na jednakost nekog društva općenito. Knjiga je podijeljena $\mathrm{u}$ tri tematska dijela »Teoretiziranje i politiziranje kućanskog rada«, »Globalizacija i društvena reprodukcija« te može promatrati i kroz dva tipa analize društvene reprodukcije koje autorica nudi. U ovom ću se prikazu ponajprije orijentirati na njih, zato on i ne treba biti shvaćen kao cjelovita obrada svih tema u knjizi.

Prvi tip analize, koji se poklapa i s prvom cjelinom knjige napisanom između 1975. i 1984. godine, odnosi se na problematiziranje društvene reprodukcije kroz prizmu neplaćenoga kućanskog rada i njegove (nepriznate) uloge u organizaciji i reprodukciji kapitalističkog društva. Pozivajući se na prijašnje prakse kapitalizma, osobito one kolonijalne, autorica tvrdi da je produktivna aktivnost kapitalizma uvijek, osim formalnoga najamnog rada, uključivala i golemu količinu neplaćenog i nevidljivog rada, poput onoga robovskog ili ženskog, a koji izravno pridonose reprodukciji kapitalizma i stvaranju viška vrijednosti (str. 19). U taj kontekst autorica smješta i kućanski rad. Naime, aktivnosti koje su nužne za nesmetanu reprodukciju kapitalizma ne počinju i ne završavaju samo na radnom mjestu, odnosno direktnom iznajmljivanju radne snage. Da bi se kapital mogao akumulirati, potrebna mu je »svježe« reproducirana radna snaga na svakodnevnoj razini. Tu reprodukciju radne snage osigurava upravo kućanski rad (str. 8). Pa ipak, kućanski je rad u kapitalističkom društvu gurnut u sferu reprodukcije, a sama reprodukci- 
ja u sferu privatnosti, pa je kao takav nevidljiv, nepriznat i neplaćen rad kojem se često negira ikakva ekonomska aktivnost i društveni doprinos. Izrečeno kroz rodnu perspektivu, to bi značilo da kapitalizam počiva na neplaćenom radu mase žena, na radu koji se obezvređuje, a često i ne vidi kao rad nego kao ženina prirodna uloga i njezin izraz ljubavi (str. 16-18, 35). No taj je rad, što ga žene obavljaju besplatno, nužan za akumulaciju kapitala. Kako kapital priznaje samo najamni rad kao produktivan i samo njega isplaćuje, kućanski rad predstavlja onaj nevidljivi dio procesa akumulacije kapitala koji međutim ne ostvaruje nikakvu nadoknadu. Žene tako ne primaju nadoknadu za rad koji već obavljaju za kapital. Problem s time, tvrdi autorica, jest i u tome što $u$ kapitalističkom društvu mnoga (socijalna) prava proizlaze samo iz najamnog rada, što ima daljnje posljedice na mogućnost njihovih ostvarivanja u slučaju mnogih koji ne pripadaju u taj odnos, iako pridonose akumulaciji kapitala. Kapital tako eksploatira žene kroz iskorištavanje patrijarhalne ideologije, ali i kroz njihov besplatan reproduktivni rad.

Dalje u prvom dijelu knjige autorica podrobnije objašnjava taj središnji argument, upućuje na razlike između njezina pristupa analizi kapitalizma $\mathrm{i}$ onog Marxova, ali i na razliku njezine analize ženskog pitanja i one prisutne kod većine feministica njezina vremena. Autorica izražava skepsu (str. 31-32, 44) prema viđenju kapitalizma kao aktera ženske emancipacije, zato je skeptična i prema strategiji izlaska žena na tržište rada koju zagovaraju brojne feministice tvrdeći da to neće riješiti pitanje reproduktivnog rada, a može završiti »duplom radnom smjenom《 za žene, osobito u kontekstu u kojem izlazak žena na tržište rada nije praćen slabljenjem uloge žena u kućanskom radu. Umjesto toga autorica je uvjerena da je strategija »plaće za kućanski rad«, koju su zagovarale feministice oko organizacije Wages for Housework, istinska revolucionarna strategija koja ima potencijal vratiti društvenu vrijednost reproduktivnom radu (str. 18-20), učiniti ga društveno priznatim i vrijednim nadoknade. Tako bi mnoge žene dobile nadoknadu za rad koji već obavljaju za kapital, izbjegle bi nužnost najamnog rada, a autorica je uvjerena kako bi ta strategija pridonijela i dekonstruiranju rodnog karaktera kućanskoga (reproduktivnog) rada (str. 58).

U druga dva dijela knjige, koji reflektiraju eseje napisane između 1999. i 2010. godine, autorica uvodi svoj drugi tip analize društvene reprodukcije, gdje središnjim postaje problematiziranje društvene reprodukcije u odnosu na procese globalizacije, odnosno na promjene koje je globalizacija donijela u globalnoj podjeli rada (str. 66-77), što prema autorici zahtijeva i sagledavanje pitanja reprodukcije s planetarne perspektive. Neki od značajnih procesa koji su obilježili globalizaciju bili su izlazak žena na tržište rada, deindustrijalizacija »naprednih" zemalja i industrijalizacija »trećeg svijeta«, pojava neoliberalnih politika demontaže socijalne države, kao i financijska kriza 
2008. godine te politike štednje koje su joj uslijedile. U tom kontekstu autorica se pita što se događa s reprodukcijom radne snage i samog života u globalnoj ekonomiji.

Tražeći odgovore na ta pitanja, autorica zaključuje kako globalizacija prije svega predstavlja povratak »primitivne akumulacije« kapitala (str. 10). Globalizacija je, suprotno optimističnim obećanjima, obilježena transferom kapitala i radne snage iz »trećeg svijeta« u napredne zemlje (str. 69-71) jednako kao i u kolonijalističko doba. Iako to na prvi pogled zvuči radikalno, autorica argumentira. Naime, industrijalizacija »trećeg svijeta« obilježena je nasilnim oduzimanjem zemlje mnogima ili njezinom reorijentacijom u izvozne svrhe za globalnu ekonomiju, čime je ugrožena društvena reprodukcija mnogih. Obilježena je industrijama u kojima je rad slabo plaćen, a radni uvjeti gotovo robovski, kao i masovnom neodgovornošću kapitala i vlada tih zemalja za reprodukciju radne snage, ili za sigurnost na radu (str. 101-109). U tom kontekstu autorica navodi kako je teško zamisliti da su žene radnice koje rade u slobodnim trgovinskim zonama »pronašle svoj spas u radu«, a mnogima od njih još uvijek ozbiljno nedostaje sredstava za društvenu reprodukciju. Za mnoge žene Trećeg svijeta društvena je reprodukcija svakodnevno upitna.

Globalizacija je prema autorici obilježena i komodifikacijom reproduktivnog rada koja se očituje na mnogim razinama. To se vidi u rastu tercijarnog sektora u naprednim zemljama što ga uglavnom čine elementi reproduktivnog rada, a u kojem su mnoge žene pronašle zaposlenje kad su izišle na tržište rada. No, ta je vrsta rada često manje plaćena, tip zaposlenja nesigurniji, a mogućnost sindikalnog organiziranja nepostojana. Komodifikacija rada očituje se i u »globalizaciji brige« (str. 108), odnosno u rijekama žena migrantica iz »trećeg svijeta« i postsocijalističkih zemalja koje napuštaju svoje zajednice i odlaze u »napredne« zemlje kako bi tamo obavljale reproduktivan rad, često nelegalno. Autorica kao napad na društvenu reprodukciju vidi i politike štednje te procese privatizacije koji se sve više pojavljuju i u »naprednim《 zemljama. Opadanje cijene rada, rastuća nezaposlenost, rezanje socijalnih davanja, kao i komodifikacija zdravstva, samo su neki od primjera ugrožavanja društvene reprodukcije koje autorica spominje. U zaključku autorica tvrdi kako, unatoč svim promjenama koje je društvena reprodukcija doživjela $u$ globalnoj ekonomiji, neke su konstante još uvijek prisutne: reproduktivan rad i dalje uglavnom obavljaju žene; njegova uloga za akumulaciju kapitala i dalje je nužna ali obezvrijeđena, a velik dio tog rada još je uvijek neplaćen; u suvremenim društvima potreba za reproduktivnim radom ne opada pa je to još uvijek aktualno pitanje u današnjoj kapitalističkoj ekonomiji (str. 9, 100).

U ostatku knjige (str. 115-148) autorica još raspravlja o novoj »politici zajedničkoga«, o pitanju »brige za starije osobe« te o novim praksama »vrtlarstva za osobne potrebe« (substance 
farming) kao novim područjima borbe i mjestima za stvaranje alternativa suvremenoj organizaciji društvene reprodukcije.

Knjiga Silvije Federici Revolution at Point Zero: Housework, Reproduction, and Feminist Struggle vrijedan je doprinos kako feminističkim tako i marksističkim teorijama društvene jednakosti, unatoč tomu što je analiza katkad površna, što bismo mogli pripisati esejističkom karakteru knjige, odnosno pisanju tijekom različitih perioda. Unatoč tomu, nema sumnje da autorica nudi drukčiju i izvornu interpretaciju spomenutih pitanja, da poziva na razmišljanje te samim time zaslužuje mjesto u suvremenim raspravama o pitanjima emancipacije žena i društvene pravednosti općenito.

Mate Ćosić Komit $\mathrm{GmbH}$, Beč

DOI: $10.5613 /$ rzs.44.2.5

\section{Mirjam Milharčič Hladnik, Jernej Mlekuž (eds)}

\section{Going Places: Slovenian Women's Stories on Migration}

Akron, Ohio: The University of Akron Press, 2014, 128 str.

U posljednjih desetak godina Institut za slovensko iseljeništvo i migracije u Ljubljani, sastavna jedinica Znan- stvenoistraživačkoga centra Slovenske akademije znanosti i umjetnosti (ZRC SAZU), objavio je niz zanimljivih publikacija iz područja migracijske problematike. U seriji monografija $\mathrm{Mi}$ gracije, prije nekoliko godina otvorena je i podzbirka Migrantke, posvećena ženskoj migracijskoj povijesti. U njoj su se, između ostalih, našle knjige Krila migracij: po meri življenjskih zgodb (2009; ur. Mirjam Milharčić Hladnik i Jernej Mlekuž) i Go Girls! When Slovenian Women Left Home (2009; ur. Marina Lukšič-Hacin i Jernej Mlekuž). Zbornik Going Places: Slovenian Women's Stories on Migration, što su ga uredili Mirjam Milharčić Hladnik i Jernej Mlekuž, pridružuje se toj tematici u američkom sveučilišnom izdanju, okupljajući djelomično prethodno objavljene radove na slovenskom (npr. u zborniku Krila migracij). Izdavač, The University of Akron Press prigodno je mjesto za objavljivanje knjige o slovenskim ženskim praksama migracije. Naime, u istoimenom je gradu u američkoj državi Ohio, 1851. godine održana Konvencija o ženskim pravima, na kojoj je afroamerička aktivistica za ženska prava, bivša ropkinja, Sojourner Truth održala govor »Ain’t I a Woman?«. Danas se smatra jednim od najpoznatijih govora u SAD-u o ukidanju ropstva i ženskim pravima. Premda tako nisu istupale, slovenske migrantice, ponajprije aleksandrinke, dikle $\mathrm{i}$ slamnikarice, stoje u dugoj liniji borbe za žensku emancipaciju i jednakost koja im je odricana i onda kad su svojim radom izvan domovine izdržavale obi- 